\title{
EPOXY-CONTAINING ADDUCTS OF ROSIN ASLIGHT- AND THERMOSTABILIZERS FOR PVC
}

\author{
${ }^{1}$ M.S. Pirguliyeva, ${ }^{2}$ A.M. Guliyev \\ ${ }^{I}$ Sumgait State University \\ AZ 5008, Sumgait, 43rd quarter, e-mail: sdtk-1959@mail.ru \\ ${ }^{2}$ Institute of Polymer Materials of the National Academy of Sciences of Azerbaijan, \\ AZ 5004, Sumgait, S.Vurgun Str., 124.e-mail: abasgulu@yandex.ru
}

Received 27.09.2020

Accepted 30.11.2020

\begin{abstract}
The thermo- and light-stabilizing activity of glycidyloxycarbonyl- and glycidyloxymethylsubstituted derivatives of the sulphur-containing rosin in the compositions on the basis of plasticized polyvinyl chloride were studied. It found that the proposed epoxy-derivative adducts of rosin possess thermal stability allowing them to withstand the processing temperature of polyvinyl chloride compositions. The developments showed that the proposed stabilizers can protect the polymer matrix against light radiation. It revealed that the film samples prepared with the help of the proposed stabilizers showed the high thermal stability, impact resistance, good frost resistance and mechanical strength.
\end{abstract}

Keywords: rosin, polyvinyl chloride, epoxy-derivative, compositions, stabilizers, thermal stability, frost resistance

DOI: $10.32737 / 2221-8688-2020-4-457-463$

\section{Introduction}

As it is known, the introduction of various additives such as plasticizers, stabilizers, antipyrenes, etc. into the composition materials is one of the main methods of adding specific properties thereto and improving physicalmechanical and technological parameters of materials [1-3]. Most synthetic polymers are noted for sufficient stability in temperature, light, atmospheric action, etc. However, this cannot be referred to PVC which is easily decomposed with $\mathrm{HCl}$ isolation in case of temperature and light influence [4].

The epoxide compounds are widely used as stabilizers for chlorine-containing polyolefins, in particular PVC. The use of epoxide compounds for PVC stabilization has a number of advantages in comparison with known stabilizers such as stearates, silicates, basic lead salts, phosphates, etc. The epoxide compounds as $\mathrm{HCl}$ acceptors cause no turbidity of the material, nor decrease electrical properties of the compositions. They are noted for good compatibility with PVC, so in this case the compositions do not sweat. Thus, the introduction of epoxy compounds into the composition of PVC-based compositions increases not only thermal, but also thermaloxidative stability and improves the physical and mechanical properties of PVC products.

The purpose of this investigation was to prepare epoxy-derivatives of rosin and their testing as co-stabilizers in the PVC composition.

\section{Experimental}

The synthesis of the sulphur-containing rosin (compounds 1 and 2) was presented in the work [5]. For preparation of the film materials, the suspension PVC of mark S-7059-M was used. Dioctyl phthalate (DOPh) was used as a plasticizer. The mixture of equal quantities of calcium and zinc stearate and complex barium- cadmium-zinc stabilizer (trademark VigostatBCC) was used as a stabilizer. Benazol-P was used as a light stabilizer.

The films samples on the basis of plasticized PVC containing stabilizers and bisadducts $\mathbf{1}$ and $\mathbf{2}$, suggested by us as co- 
stabilizers were obtained by means of compositions rolling.

The PVC-based compositions with addition of synthesized bis-adducts were prepared by mixing components in the Brabender mixer. Then they were subjected to gelatinization and plasticization by keeping them in an oven at $90^{\circ} \mathrm{C}$ for $1.5-2.0 \mathrm{~h}$. After that the rolling was produced at $150^{\circ} \mathrm{C}$ for $10 \mathrm{~min}$., and then there was performed the pressing at the same temperature and pressure 5.0 $\mathrm{MPa}$ for 10 min. The cooling was carried out with water. The content of bis-adduct per 100 mass p. of PVC was 2 mass p. The composition mixtures were made both with the participation of calcium and barium stearates and without them.

The films of plasticized PVC containing the stabilizers synthesized by us were obtained on rollers. The stabilizers were preliminarily dissolved and added to PVC. The mixture swelling was carried out in an oven at $110^{\circ} \mathrm{C}$ for $1 \mathrm{~h}$. The plasticization was realized at $160^{\circ} \mathrm{C}$ on the rollers till preparation of a homogeneous mass. The films were obtained on a four-roll laboratory calender at roll temperature 150$165^{\circ} \mathrm{C}$. The films thickness was $0.3 \pm 0.05 \mathrm{~mm}$.

The thermo-gravimetric analysis of samples and initial products was carried out on Paulik-Paulik-Erdei derivatograph (heating rate $\left.-5^{\circ} \mathrm{C} / \mathrm{min}\right)$.

The light-warm aging of samples was carried out at temperature $70^{\circ} \mathrm{C}$ under lamp DPT-375 for $72 \mathrm{~h}$ (according to GOST 8979-75) [6]. The physical-mechanical parameters were determined on a tensile testing machine PM-301.

\section{Results and discussion}

In search of effective stabilizers, we worked out sulphur-containing epoxide compounds on the basis of accessible alternative raw material - rosin. The synthesis of intended adducts (compounds $\mathbf{1}$ and 2 ) was carried out by two methods [5]:

- preparation of glycidyl esters of rosin and its hydroxymethyl derivative with the subsequent addition of ethanedithiol thereto under conditions of the radical initiation;

- radical addition of ethanedithiol to rosin or its hydroxymethyl derivative with preparation of carboxyl- and hydroxyl-containing bis-adducts, then the synthesis of adducts of the appropriate glycidyl esters on their basis.

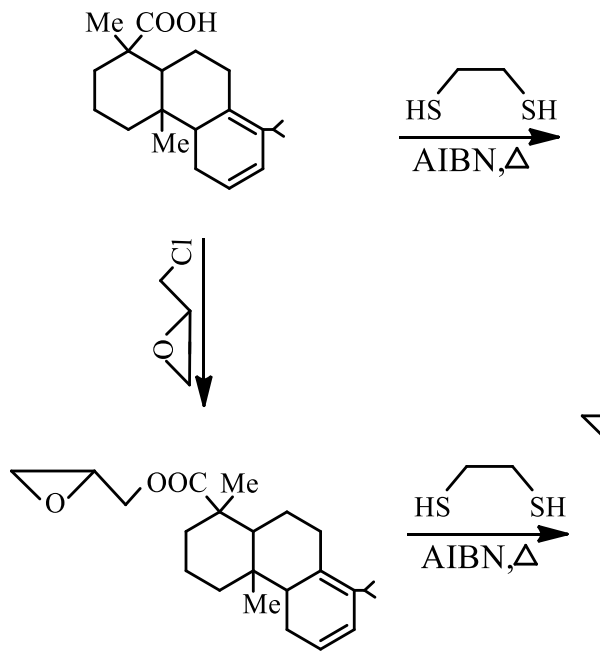

The glycidyl ester of rosin (as levopimaric acid) was obtained by means of the reaction of sodium salt of acid with epichlorohydrin. The reaction of glycidyl ester of levopimaric acid with ethanedithiol was carried out in the presence of AIBN at temperature $70^{\circ} \mathrm{C}$ for 60 -
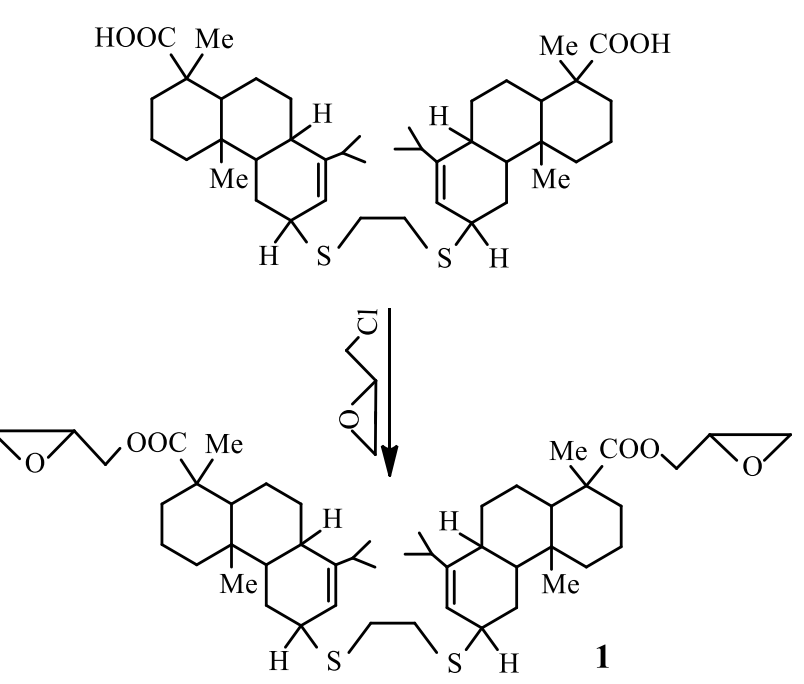

$120 \mathrm{~min}$. AIBN was taken in a quantity of 0.5 mass\%, and the ratio of glycidyl ester of levopimaric acid to ethanedithiol was $2: 1$. The bis-adducts (compounds 1 and 2) were obtained with almost quantitative yields. According to a similar scheme, the bis-adduct (compound 2) - 
glycidyloxymethyl derivative rosin was rosin.

obtained from hydroxymethyl derivative of

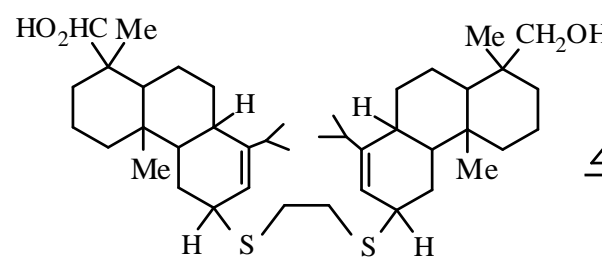

Using GPC analysis method, it found that the obtained adducts $\mathbf{1}$ and $\mathbf{2}$ are the individual compounds with MW=807 (calculated 810) and 778 (calculated 782), respectively. These compounds were low-viscous products that were easily dissolved in many organic solvents.

The epoxide compounds 1 and 2, containing tricyclic rosin fragments in a molecule, developed by us, are compatible with PVC, and as will be shown below, possess stabilizing properties.

The tests showed that the epoxide compounds worked out by us have higher thermal stability. Due to good compatibility

Table 1. Thermal characteristics of sulphur-containing epoxy-derivatives of rosin and industrial catalysts

\begin{tabular}{|l|c|c|c|}
\hline \multirow{2}{*}{ Compound } & \multicolumn{3}{|c|}{ Results of thermal analysis } \\
\cline { 2 - 4 } & $\mathbf{T}_{\text {begin., }}{ }^{\mathbf{0}} \mathbf{C}$ & $\mathbf{T}_{\text {end. }}{ }^{\mathbf{0}} \mathbf{C}$ & $\mathbf{E}_{\text {eff., }} \mathbf{~ k J / m o l}$ \\
\hline Compound 1 & 243 & 306 & 40.9 \\
\hline Compound 2 & 252 & 302 & 42.2 \\
\hline Vigostab-BCC & 257 & 325 & 44.7 \\
\hline
\end{tabular}

It follows from Table 1 that $\mathrm{T}_{\text {begin. }}$ value of decomposition of the sulfur-containing epoxy derivatives of rosin (compounds $\mathbf{1}$ and 2) and known stabilizers used in industry have similar values, while $\mathrm{T}_{\text {end }}$ value of decomposition of these samples strongly differed. Moreover, the samples proposed by us have considerably higher values. This is evidenced by the value of their $E_{\text {ef. }}$ termodestruction. All this has probably been connected with structural peculiarities (polycyclic structure) of the proposed stabilizers.

For estimation of the possibility of the use of the synthesized compounds as thermo- and light-stabilizers, the compositions on the basis of PVC with the use of DOPh plasticizer (40 with PVC, these compounds do not migrate to the surface of products made.

For estimation of the beginning ( $T_{\text {begin. }}$ ) and the final $\left(\mathrm{T}_{\text {end }}\right)$ temperatures of thermal decomposition of the samples and for calculation of the activation energy $E_{a}$ of the thermal destruction process, we used TGA method (Table 1) [7]. To compare the obtained data with the data of industrial stabilizers, TGAcurves were taken for samples with the help of light stabilizers used: Benazol-P, thermostabilizer - calcium stearate and Vigostab-BCC. mass \% per 100 mass \% of PVC) had been prepared. The films made from these compositions were then subjected to the thermogravimetric analysis (Table 2). The obtained data show that the values of both $\mathrm{T}_{\text {begin. and }} \mathrm{T}_{\text {end }}$ increased when used as proposed additives. For estimation of the synthesized compounds as the light-stabilizers they were subjected to the accelerated light aging. Their efficiency was determined by values of stability coefficients on strength $\left(K_{\sigma}\right)$ and relative elongation $\left(K_{\varepsilon}\right)$. These parameters were identified as the percentage of retention of composition properties after light-warm aging [8]. 
Table 2. Some thermal and physical-mechanical characteristics of films made with the participation of proposed and known stabilizers (PVC - 100 mass $\mathrm{p}, \mathrm{DOPh}-40$ mass $\mathrm{p}$, stabilizer -2 mass $\mathrm{p}$, co-stabilizer - 2 mass p.).

\begin{tabular}{|l|c|c|c|c|c|}
\hline \multirow{2}{*}{ Stabilizer } & \multicolumn{3}{|c|}{ Results of thermal analysis } & \multicolumn{2}{c|}{ Light-warm aging } \\
\cline { 2 - 6 } & $\mathbf{T}_{\text {begin., }}{ }^{\mathbf{0}} \mathbf{C}$ & $\mathbf{T}_{\text {end., }}{ }^{\mathbf{0}} \mathbf{C}$ & $\mathbf{E}_{\text {eff., }} \mathbf{k J} / \mathbf{m o l}$ & $\mathbf{K}_{\boldsymbol{\sigma}}, \boldsymbol{\%}$ & $\mathbf{K}_{\boldsymbol{\varepsilon}}, \boldsymbol{\%}$ \\
\hline Compound 1 & 197 & 282 & 116.2 & 0.99 & 1.09 \\
\hline Compound 2 & 202 & 296 & 113.6 & 1.04 & 1.02 \\
\hline Vigostab-BCC** & 195 & 292 & 114.9 & 95.3 & 97.2 \\
\hline
\end{tabular}

* - determined by [6];

** - data of works [8].

The test results showed that films made of PVC-compositions and stabilized by both the proposed compounds and standard stabilizers, after light-warm aging, in a case of using new additives, exceed the known ones. The

stabilizing action of the used compounds has been studied by determination of $\mathrm{HCl}$ quantity, isolating as a result of effect of high temperature or light on composition (Table 3) [9].

Table 3. Stabilizing capacity of epoxy-containing derivatives of rosin (quantity of co-stabilizer 2.0 mass p. per 100 mass p. of PVC).

\begin{tabular}{|c|c|c|c|c|}
\hline $\begin{array}{c}\text { Code of } \\
\text { compo- } \\
\text { unds }\end{array}$ & MW & $\begin{array}{c}\text { Epoxide number, \% } \\
\text { found/calculated }\end{array}$ & $\begin{array}{c}\text { Loss temperature } \\
\text { of 5\% } \\
\text { mass, }{ }^{\mathbf{0}} \mathbf{C}^{*}\end{array}$ & $\begin{array}{c}\text { Time before beginning of HCl } \\
\text { isolation at } \mathbf{1 7 5}^{\mathbf{}} \mathbf{C}, \mathbf{~ m i n}^{* *}\end{array}$ \\
\hline $\mathbf{1}$ & 810 & $10.2 / 10.62$ & 285 & 45 \\
\hline $\mathbf{2}$ & 782 & $10.88 / 11.00$ & 280 & 48 \\
\hline
\end{tabular}

It follows from the data in Table 3 that as the content of epoxide groups increased, their stabilizing action increased as well. In this case, the efficiency of the stabilizing action of the proposed compounds is determined by the starting temperature of decomposition (at the defined heating rate) and the duration of induction period. The experiments showed that in all cases there is observed an availability of the induction period that is increased as the content of the epoxide groups increased and decreased with rise in temperature (Table 4).

Table 4. Influence of epoxy-containing derivatives of rosin on changes in the induction period and decomposition temperature of the PVC-based compositions at various temperatures.

\begin{tabular}{|c|c|c|c|c|}
\hline \multirow[t]{2}{*}{ Composition } & \multicolumn{3}{|c|}{$\begin{array}{c}\text { Induction period (time before beginning of } \mathrm{HCl} \\
\text { isolation at temperature), min }\end{array}$} & \multirow{2}{*}{$\begin{array}{c}\text { Decomposition } \\
\text { temperature, } \\
{ }^{\circ} \mathrm{C}\end{array}$} \\
\hline & $150^{\circ} \mathrm{C}$ & $175^{\circ} \mathrm{C}$ & $190^{\circ} \mathrm{C}$ & \\
\hline PVC & 18 & 6 & - & 168 \\
\hline PVC + comp.1 & 64 & 43 & 8 & 187 \\
\hline PVC + comp.2 & 69 & 48 & 9 & 193 \\
\hline
\end{tabular}

It should be noted that the stabilizing activity of adducts 1 and 2 has been connected with availability of the sulfur atoms and epoxide group in the molecules of these compounds, easily reacting with $\mathrm{HCl}$, isolated from $\mathrm{PVC}$ under action of temperature and light. Consequently, under the influence of the 
epoxide additives, PVC dehydrochlorination rate falls sharply.

Compositions made on the basis of PVC with the use of epoxy-containing compounds 1 and 2, having sulfur atoms as sulfide bond along with epoxide groups in their composition, have higher impact resistance, good frost resistance and mechanical properties (Table 5).

Table 5. Some properties of the PVC-based compositions with the use of epoxy-derivatives of bisadduct of ethanedithiol with rosin

\begin{tabular}{|c|c|c|c|c|}
\hline \multirow[b]{2}{*}{ Name of index } & \multicolumn{4}{|c|}{$\begin{array}{c}\text { Components included in the composition on } \\
\text { the basis of PVC }\end{array}$} \\
\hline & $\begin{array}{c}\operatorname{DOPh}(40)^{*} \\
\text { Calcium } \\
\text { and barium } \\
\text { stearate (2) }\end{array}$ & \begin{tabular}{|l} 
DOPh (40) \\
Comp.1(2) \\
\end{tabular} & $\begin{array}{c}\text { DOPh (20) } \\
\text { Comp.2 }(20)\end{array}$ & DOPh (40) \\
\hline Tensile strength, MPa & 19.6 & 19.8 & 19.6 & 19.0 \\
\hline Specific elongation at break, $\%$ & 246 & 243 & 242 & 250 \\
\hline Tensile modulus of elasticity, MPa & 11.8 & 11.7 & 11.6 & 11.8 \\
\hline Induction period at $170^{\circ} \mathrm{C}, \mathrm{min}$. & 320 & 316 & 316 & 285 \\
\hline Frost resistance, ${ }^{\circ} \mathrm{C}$ & -51 & -52 & -52 & -50 \\
\hline Volatile, $\%$ (at $100^{\circ} \mathrm{C}, 1 \mathrm{~h}$ under vacuum) & 0.29 & 0.26 & 0.20 & 0.31 \\
\hline Decomposition temperature, ${ }^{\circ} \mathrm{C}$ & 293 & 290 & 292 & 286 \\
\hline
\end{tabular}

*-the content in mass p. is indicated in parentheses.

The values identified in the physicalmechanical and other properties of the prepared compositions showed that tensile strength, specific elongation at break and modulus of elasticity at $100 \%$ deformation are at the level of indices of compositions made only with the participation of widely used plasticizer DOPh and stabilizers - calcium and barium stearates [11].

Thus, it revealed that the synthesized epoxy-containing compounds in the composition of PVC-compositions show their stabilizing effect and can be used as stabilizers for PVC. It found that in this case the compositions made on the basis of PVC with the use of these compounds had relatively better indices in physical-mechanical properties as compared to indices of compositions made in the absence of these compounds.

\section{References}

1. Akhmadullin R.M., Gatiyatullin D.R., Vasiliev L.A. and others. The effectiveness of 4,4-bis (2,6-di-tert-butylphenol) and in the stabilization of isoprene rubber and polypropylene. The Russian Journal of Applied Chemistry. 2015, vol. 88, no. 5, pp. 792-797.

2. Maslova I.P., Zolotareva K.A., Glazunova N.A. and other Chemical additives to polymers. Directory. Moscow: Himiya Publ., 1973, 272 p.

3. Minsker K.S., Kolesov SV., Zaikov G.E. Aging and stabilization of vinyl chloridebased polymers. Moscow. 1982, p. 67.

4. Wilkie C., Summers J., Daniels C.
Polyvinyl chloride. 2007, 728 p.

5. Pirgulieva M.S. Rosin-based sulfurcontaining epoxy compounds - stabilizers for PVC. Collection of materials XII Numanovsikh readings "State and prospects of development of organic chemistry in the Republic. Tajikistan. Dushanbe, 25.11.2015, pp. 11-13 (In Russian).

6. ГОСТ 8979-75. Artificial leather and film materials. Methods for determining resistance to thermal and light-thermal aging. (In Russian).

7. Shakhnazarli R.Z., Ishchenko N.Ya., Makarenko O.A., Guliev A.M. Free radical functionalization of polypropylene by 
grafting

with

vinyloxycyclopropanecarboxylic acid under conditions of reactive extrusion. Polimernye materialy i tehnologii. 2019, vol. 5, no. 1, pp. 26-32. (In Russian).

8. Kuvshinova S.A., Syrbu E.S., Novikov I.V. etc. Molecular anisotropic derivatives of phenyl benzoate as stabilizers of compositions based on plasticized polyvinyl chloride. The Russian Journal of Applied Chemistry. 2015, vol. 88, no. 2, pp. 325-331.

9. Folarin O.M., Sadiku E.R. Thermal stabilizers for poly(vinyl chloride): A review. Int. J. Phys. Sci. 2011, vol. 6, no. 18, pp. 4323-4330.

10. Pirgulieva M.S. New curable rosin-based epoxy compounds. Proceedings of the VI International Scientific and Practical Conference "International innovation research". Russia, Penza, 2017, pp. 19-25.

11. Sabaa M.W., Mohamed R.R., Yassin A.A. Organic thermal stabilizers for rigid poly(vinyl chloride). Part X. N-acryloyl-N'$p$-substituted phenylthiourea derivatives. $J$. Polym. Degrad. Stab. 2003, vol. 82, no. 3, pp. 387-393.

\title{
KANIFOLUN EPOKSITORKİBLİ ADDUKTLARININ PVX ÜÇÜN İŞIQ VӘ TERMOSTABILIZATORLAR KIMI İSTIFADəSİ
}

\author{
${ }^{1}$ M.S. Pirquliyeva, ${ }^{2}$ A.M. Quliyev \\ ${ }^{1}$ Sumqaylt Dövlat Universiteti \\ AZ 5008, Sumqayıt şəh., 43 mahalla. E-mail: sdtk-1959@mail.ru \\ ${ }^{2}$ AMEA, Polimer Materiallarl Institutu \\ AZ 5004, Sumqayıt şəh., S.Vurğun küç., 124.E-mail: abasgulu@yandex.ru
}

Kükürd torkibli qlisidoksikarbonil vo qlisidoksimetil avazli kanifoldan istifado etməklo plastifikasiya edilmiş PVX asasında hazırlanmış kompozitlorin temperatura vo işı̆̆a qarşı stabilliyi öyronilmişdir. Müəyyən edilmişdir ki, kanifol asasında hazırlanmış epoksid torkibli adduktlar termiki davamlıdırlar va onlar PVX kompozisiyaların emal temperaturuna dözürlar. Göstərilmişdir $\mathrm{ki}$, təklif olunan stabilizatorlar polimer matrisini işıq selindən qorumaq xüsusiyyətina malikdirlar. Müəyyən edilmişdir ki, təklif olunan stabilizatorlardan istifado etməklo hazırlanmış kompozisiya nümunalari yüksək temperatura, zarbəyə və şaxtaya davamlılıq vo mexaniki möhkəmlik xüsusiyyatlari özünda aks etdirirlar.

Açar sözlor: kanifol, polivinilxlopid, epoksid, stabilizator, temperatura davamlılıq, mexaniki möhkamlik

\section{ЭПОКСИСОДЕРЖАЩИЕ АДДУКТЫ КАНИФОЛИ В КАЧЕСТВЕ СВЕТО- И ТЕРМОСТАБИЛИЗАТОРОВ ДЛЯ ПВХ}

\author{
${ }^{1}$ М.С. Пиргулиева, ${ }^{2}$ А.М. Гулиев \\ ${ }^{1}$ Сумгаитский государственный университет \\ AZ 5008, г.Сумгайыт, 43 квартал.E-mail: sdtk-1959@mail.ru \\ ${ }^{2}$ Институт Полимерных Материалов НАН Азербайджана, \\ AZ 5004, г.Сумгайыт, ул С.Вургуна, 124.E-mail: abasgulu@yandex.ru
}


Изучена термо- и светостабилизирующая активность глищидилоксикарбонил- $u$ глицидилоксиметилзамещенных производных серосодержащей канифоли в композициях на основе пластифицированного поливинилхлорида. Показано, что предложенные эпоксипроизводнье аддукть канифоли обладают термической устойчивостью, позволяющей им выдерживать температуру переработки поливинилхлоридных композищий. Разработки показали, что предложенные стабилизаторы способны защчттить полимерную матрииу от светового излучения. Установлено, что изготовленные с участием предложенных стабилизаторов пленочные образиы проявляют высокую термическую устойчивость, ударопрочность, хорочую морозостойкость и механическую прочность.

Ключевье слова: канифоль, поливинилхлорид, эпоксипроизводные, стабилизатор, термическая устойчивость, ударопрочность, 